\title{
Variation in serum electrolytes and enzyme concentrations in patients with sickle cell disease
}

N Nduka, Y Kazem, B Saleh

\begin{abstract}
Aim-To assess levels of some biochemical variables in sickle cell disease patients from eastern Saudi Arabia during steady state and in crises states, with a view to comparing biochemical and clinical manifestations of the disease with those in other geographical locations.

Methods-Serum calcium, uric acid, total bilirubin, lactate dehydrogenase, hydroxybutyrate dehydrogenase, and haemoglobin were measured in 110 sickle cell patients when in steady state. The same variables were measured on 30 of the patients when they went into crisis.

Results-Serum calcium tended to be lower in sickle cell patients than in healthy controls, while uric acid tended to be in the high normal range. Crises did not make any difference to serum calcium but they increased the uric acid level significantly. All the other variables measured were significantly abnormal and more so during crises.

Conclusions-Although the abnormal levels obtained for these biochemical variables in patients with sickle cell disease from eastern Saudi Arabia were similar to those from other geographical locations, there were noticeable differences in the severity of the abnormalities, which probably explains the differences in the clinical manifestations of the disease between geographical locations. Values of some of these variables could be adapted for use to monitor crises.

(f Clin Pathol 1995;48:648-651)
\end{abstract}

Keywords: Sickle cell disease, biochemical variables, Saudi Arabia.

Qatif Central

Hospital, Al Jeshi

31911, Saudi Arabia:

Department of

Clinical Biochemistry

N Nduka

Department of

Haematology

Y Kazem

B Saleh

Correspondence to: Dr Nsirim Nduka, Department of Clinical Bepartment of Clinical Biochemistry, Asir Central
Hospital, PO Box 34, Abha Hospital, PO Box 34, Abha,
Kingdom of Saudi Arabia. Accepted for publication 20 December 1994
Various biochemical manifestations of sickle cell disease are now well documented ${ }^{1-6}$ and the possible roles that these play in the pathophysiology of the disease have been proposed. The role of calcium homeostasis as it affects pathological changes in the skeletal system in sickle cell disease has recently attracted attention. ${ }^{67}$ In one such report, ${ }^{7}$ radiological bone changes were strongly associated with the greater severity of the disease in one region of Saudi Arabia compared to other regions of the same country. While low serum calcium has been reported in the southwestern province of Saudi Arabia, no such studies have been carried out in the eastern province, where the severity of sickle cell disease is reported to be milder. ${ }^{7-9}$

We have recently proposed a possible in vitro antisickling role for uric acid in sickle cell disease ${ }^{3}$ and we deduced that this could be responsible for a tendency towards hyperuricaemia and its attendant consequences $^{1011}$ in sickle cell disease patients. Furthermore, there is commonly an increase in lactate dehydrogenase $(\mathrm{LDH})^{5}$ as well as total bilirubin levels ${ }^{12}$ in these patients. Changes in these indices are often associated with haemolytic episodes, which are a common feature of the disease. Whether there is a correlation between the serum levels of these two variables in sickle cell patients, or between the changes in their levels and the perennially low haemoglobin levels common in this disease, is not obvious. Also, it has been reported that both haemoglobin and total bilirubin levels are unaffected during painful crisis and that crises are milder in tropical regions. ${ }^{12}$ Whether crises bring about alterations from the norm in these biochemical values, such as the reported increase in serum $\alpha$-hydroxybutyrate in painful crises, ${ }^{13}$ has not been reported in this population, which has milder manifestations of the disease.

We have focused on the serum calcium concentrations and the other biochemical variables mentioned above as a basis for a comparative assessment of the biochemical manifestations of sickle cell disease, and what bearing they may have on the pathophysiology of patients with this disease in our own locality compared to others, bearing in mind the known variations in the manifestations of the disease in different geographical locations around the world. ${ }^{1415}$

\section{Methods}

One hundred and ten Saudis with sickle cell disease (HbSS) were investigated in this study. There were 60 males and 50 females, with ages ranging from 5 to 50 years (mean 18 years). One hundred healthy matching controls (HbAA subjects) were similarly investigated. The control subjects were taken at random but often included relatives of the sickle cell disease patients. The sickle cell patients were either regular attendants at the sickle cell clinic or were seen in the emergency unit of the 500 bed Qatif Central Hospital in the eastern province of Saudi Arabia. The patients from the emergency unit were usually in crisis state, while those seen at the sickle cell disease clinic were mainly in non-crisis steady states. 
Table 1 Level of some biochemical variables in Saudi sickle cell disease patients, and in age and sex matched controls. Values are means (SD)

\begin{tabular}{|c|c|c|c|c|}
\hline \multirow[b]{2}{*}{ Biochemical variables } & \multirow[b]{2}{*}{ Group } & \multicolumn{2}{|c|}{ Haemoglobin phenotype } & \multirow{2}{*}{$\begin{array}{l}\text { Statistical } \\
\text { significance } \\
(S S v A A)\end{array}$} \\
\hline & & $S S$ & $A A$ & \\
\hline $\begin{array}{l}\text { Calcium }(\mathrm{mmol} / \mathrm{l}) \\
\text { Uric acid (mg/dl) } \\
\text { Total bilirubin (mg/dl) } \\
\text { LDH (U/l) } \\
\alpha-\mathrm{HBDH}(\mathrm{U} / \mathrm{l}) \\
\mathrm{Hb}(\mathrm{g} / \mathrm{dl})\end{array}$ & $\begin{array}{l}\text { Male + female } \\
\text { Male } \\
\text { Female } \\
\text { Male + female } \\
\text { Male + female } \\
\text { Male + female } \\
\text { Male + female } \\
\text { Male } \\
\text { Female }\end{array}$ & $\begin{array}{l}2 \cdot 22(0 \cdot 04) \\
4 \cdot 81(1 \cdot 20) \\
4 \cdot 15(1 \cdot 23) \\
2 \cdot 46(1 \cdot 32) \\
356(51) \\
220(24) \\
9 \cdot 26(1 \cdot 92) \\
9 \cdot 17(1 \cdot 87) \\
9 \cdot 10(1 \cdot 89)\end{array}$ & $\begin{array}{l}2.5(0.03) \\
4 \cdot 3(0.92) \\
3.5(0.94) \\
0 \cdot 7(0.05) \\
177(29) \\
121(16) \\
14 \cdot 83(1.51) \\
15 \cdot 11(1.39) \\
13.71(1.42)\end{array}$ & $\begin{array}{l}\text { Not significant } \\
\text { Not significant } \\
\text { Not significant } \\
p<0.001 \\
p<0.001 \\
p<0.001 \\
p<0.001 \\
p<0.001 \\
p<0.001\end{array}$ \\
\hline
\end{tabular}

$\mathrm{LDH}=$ lactic dehydrogenase; $\alpha$ - $\mathrm{HBDH}=\alpha$-hydroxybutyrate dehydrogenase

Blood samples were drawn from all the patients and control subjects. Because many of the patients were regular attendants of the sickle cell disease clinic as well as being admitted sometimes to the emergency unit when in crisis, it was possible to draw blood from them before, during, and after sickling crises. Samples were therefore obtained for steady states and for crisis states for 30 of the sickle cell disease patients. Eighty five per cent of the crisis states were of the vaso-occlusive type. Aliquots of the blood samples drawn from each patient or control subject were dispensed into appropriate tubes for haematological and biochemical studies. Haemoglobin values were obtained for every subject. Plasma was obtained by centrifugation of the samples for biochemical studies and used for the estimation of total bilirubin, calcium, uric acid, $\mathrm{LDH}$, and the LDH1

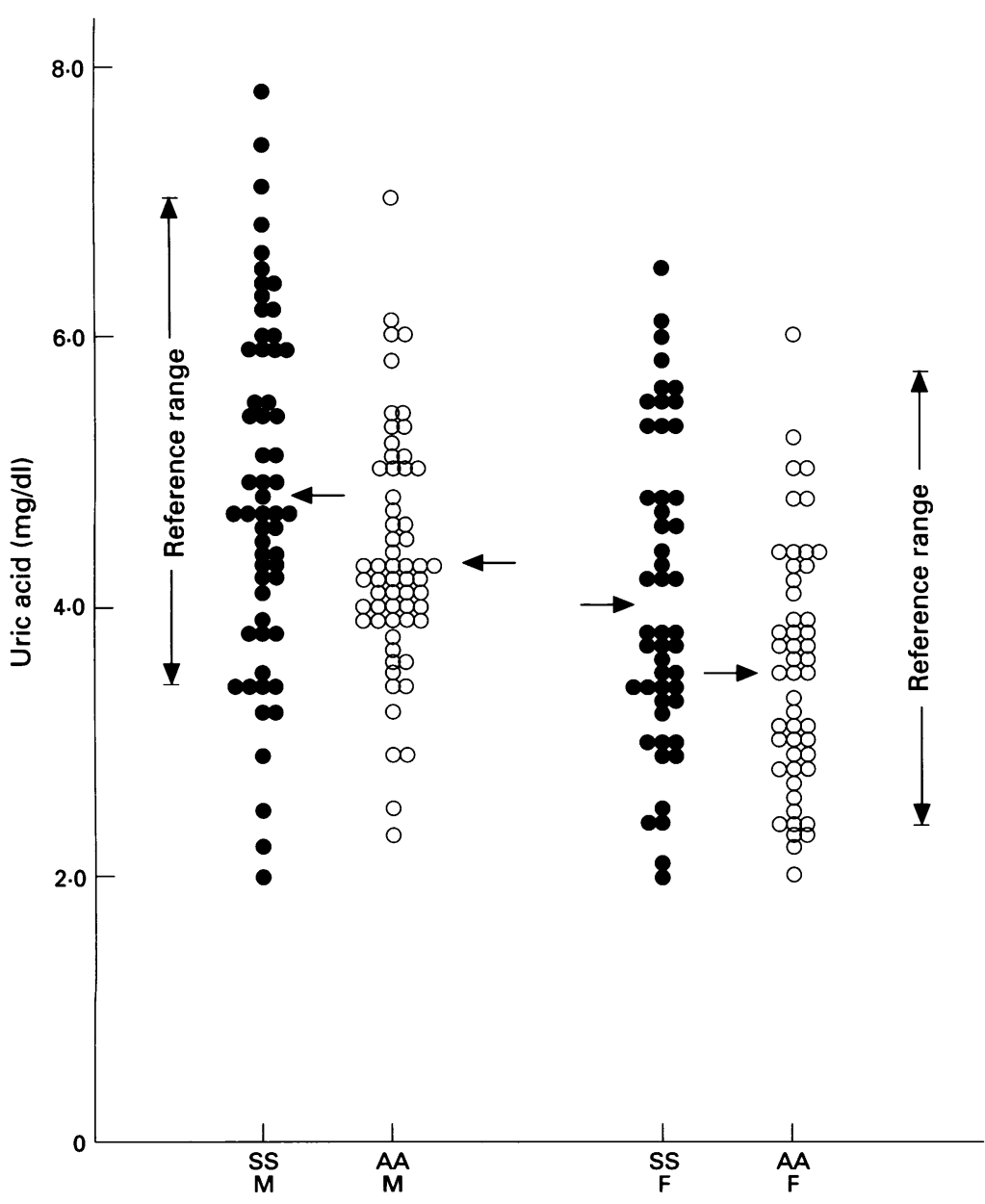

Figure 1 Distribution of uric acid levels in $H b S S$ patients and $H b A A$ controls. $(M=$ males; $F=$ females; arrows indicate mean values) oxobutyrate substrate analogue, $\alpha$-hydroxybutyrate dehydrogenase ( $\alpha-\mathrm{HBDH})$.

Haemoglobin estimation was carried out with a Coulter counter S-plus IV model. Analyses of the biochemical variables were done with the Astra systems autoanalyser, except for the enzymes, which were analysed with the Dupont Dimension autoanalyser. Ciba "normal" and "abnormal" quality control sera were used for all the analyses. Coefficients of variation for the assays in our laboratory were $6.2 \%$ (bilirubin), $4 \cdot 6 \%$ (calcium), $4 \cdot 3 \%$ (uric acid), $6.3 \%$ (LDH and $\mathrm{HBDH}$ ).

Statistical analysis was done using Student's $t$ test to obtain statistical significance of the differences between the mean for each variable in the sickle cell disease patients compared to the control (HbAA) subjects. $P$ values $<0.05$ were considered significant. Data are presented as mean (SD), and $95 \%$ confidence interval (CI), with significance of difference between means evaluated by unpaired CI testing.

\section{Results}

Values of the various biochemical variables for the different subject groups investigated are presented in table 1 . The statistical significance between the mean values for sickle cell disease patients and their matched controls (HbAA) are indicated in the table. The distribution of uric acid levels in the two groups of subjects is shown in fig 1 .

The results show that the mean serum calcium level was lower, while the uric acid level was higher, in the sickle cell disease patients than in the control subjects. The differences in the mean values are not statistically significant, though fig 1 shows that the uric acid levels tended towards the higher values of the reference range. However, only three patients had hyperuricaemic levels. Total bilirubin, LDH and $\alpha-\mathrm{HBDH}$ were significantly higher, while the $\mathrm{Hb}$ values were significantly lower, in the sickle cell disease patients than in the control subjects, as indicated in table 1 .

Table 2 shows the values for the various biochemical indices when the sickle cell patients were in crisis as opposed to the steady state. It shows that the values were statistically different depending on whether the patient was in crisis or in the steady state. This is illustrated further for uric acid in fig 2 , which shows the distribution of the values in the two states. The exception was the calcium values, which remained the same irrespective of whether or 
Table 2 Level of some biochemical variables of sickle cell disease patients when in crisis and steady states. Values are means (SD)

\begin{tabular}{llll}
\hline $\begin{array}{l}\text { Biochemical } \\
\text { variables }\end{array}$ & $\begin{array}{l}\text { In crisis } \\
\text { state }\end{array}$ & $\begin{array}{l}\text { In steady } \\
\text { state }\end{array}$ & $\begin{array}{l}\text { Statistical } \\
\text { significance }\end{array}$ \\
\hline Uric acid (mg/dl) & $5 \cdot 10(0 \cdot 91)$ & $4 \cdot 41(0 \cdot 90)$ & $\mathrm{p}<0.05$ \\
Total bilirubin (mg/dl) & $4 \cdot 01(1 \cdot 10)$ & $2 \cdot 03(0 \cdot 72)$ & $\mathrm{p}<0.001$ \\
$\mathrm{LDH}(\mathrm{U} / \mathrm{l})$ & $522(54)$ & $290(22)$ & $\mathrm{p}<0.001$ \\
$\alpha-\mathrm{HBDH}(\mathrm{U} / \mathrm{l})$ & $288(24)$ & $204(19)$ & $\mathrm{p}<0.002$ \\
$\mathrm{Hb}(\mathrm{g} / \mathrm{dl})$ & $7 \cdot 55(1 \cdot 01)$ & $9 \cdot 53(1 \cdot 33)$ & $\mathrm{p}<0.01$ \\
$\mathrm{Ca}^{2+} \mathrm{mmol} / \mathrm{l}$ & $2 \cdot 22(0 \cdot 04)$ & $2 \cdot 24(0.04)$ & $\mathrm{NS}$ \\
\hline
\end{tabular}

$\mathrm{LDH}=$ lactate dehydrogenase; $\alpha-\mathrm{HBDH}=\alpha$-hydroxybutyrate dehydrogenase; $\mathrm{Hb}=$ haemoglobin.

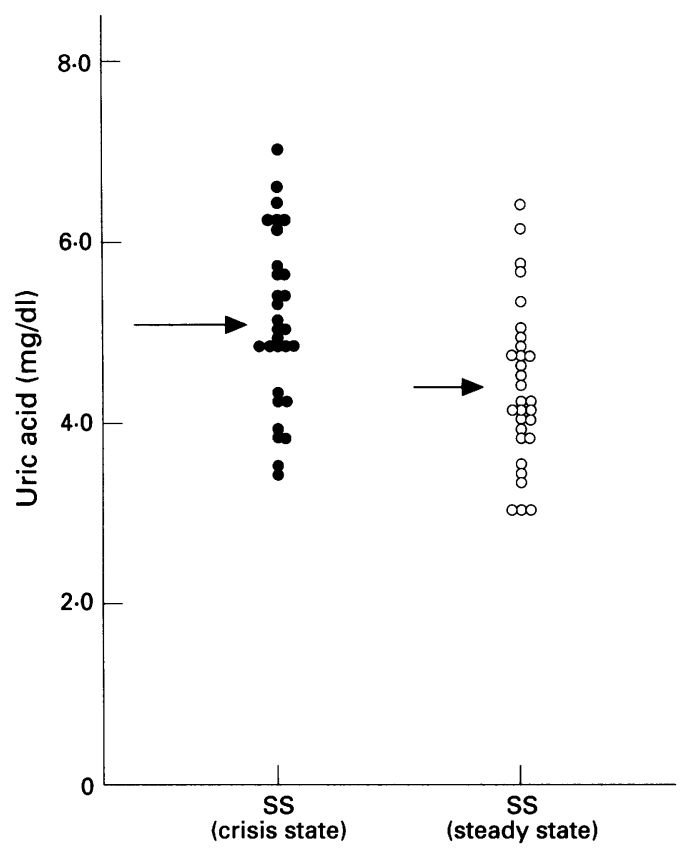

Figure 2 Distribution of uric acid levels in $\mathrm{HbSS}$ patients in crisis state and in steady state. Arrows indicate mean values.

not the patient was in crisis. Uric acid, total bilirubin, $\mathrm{LDH}$, and $\alpha-\mathrm{HBDH}$ levels were higher, while the $\mathrm{Hb}$ level was lower, during crisis than during steady state.

\section{Discussion}

There is evidence now to show that calcium homeostasis is affected in sickle cell disease. ${ }^{267}$ A tendency towards hypocalcaemia in these patients has been found in our study, as in others. ${ }^{267}$ The fact that patients with sickle cell disease are not universally hypocalcaemic may be explained by the complex nature of calcium homeostasis and the possible role of vitamins and hormones, as suggested recently. ${ }^{6}$ It might have been expected that the milder nature of the disease in eastern Saudi Arabia would result in better calcium homeostasis. This has not been found to be true in our study. The similarity of our results to those of others ${ }^{267}$ and the absence of variation in the calcium levels between crisis and steady state periods of sickle cell disease strongly suggest that the commonest presenting feature of the disease-the bone manifestations ${ }^{27}$-is an inherent aspect of the disease and does not depend on the geographical location of the patients. Therefore the suggestion that the radiological bone changes per $\mathrm{se}^{7}$ could be strongly associated with the greater severity of the disease between one geographical location and another should be viewed with caution, as other factors are in fact implicated. ${ }^{689}$ These other factors, which have geographical variability, may be the underlying factors that affect calcium homeostasis and consequently produce variable bony manifestations from one population of sickle cell disease sufferers to another.

From this study, we have shown that serum uric acid values in sickle cell patients tend towards the upper range of normal, but with only about $3 \%$ reaching the hyperuricaemic level. This tendency is similar to previous reports on Saudi Arabian sickle cell patients ${ }^{4}$ and other populations. ${ }^{2101617}$ However, our results and the others published on Saudis ${ }^{4}$ show that the rise in uric acid is generally less in the Saudi Arabian population than in other regions. However, the significant difference in values between crisis and steady state is similar to that reported in a Nigerian population during bone pain crisis. ${ }^{17}$ The similarity is underscored by the fact that over $80 \%$ of the crises in our population were of the painful vaso-occlusive type which also inflicts bone pain on the patients. The fact that the uric acid elevation reverted to normal upon recovery from crisis lends credence to the suggestion of an antisickling role for uric acid. ${ }^{3}$ It seems plausible, therefore, for us to infer from these findings that uric acid metabolism is compromised in sickle cell disease, albeit to a varying degree depending on ameliorating factors. ${ }^{9}$ Thus, the severity and consequences of the manifestations of sickle cell disease, depending on sex, age, and type of population, also vary. ${ }^{45101617}$

Bearing in mind the implications of hyperuricaemia on renal integrity, ${ }^{1018}$ we suggest more regular monitoring of uric acid levels, especially in older sickle cell disease patients in whom prolonged hyperuricaemia may have cumulative adverse effects on the kidneys.

A rise in bilirubin is not unexpected since there is a higher than normal rate of breakdown of red blood cells in sickle cell disease patients. Also, sickle cell disease related infarcts, occurring in a variety of organs including the liver, have been reported. ${ }^{19}$ Microinfarcts in the liver could exacerbate the rise in serum bilirubin and would account for the much higher level in crisis. Similarly, the low level of haemoglobin, which is further reduced in crises as observed in this study, is attributed to the continuous haemolysis in sickle cell disease. This is similar to the results in Nigerian sickle cell patients. ${ }^{15}$ However, the haemoglobin values in both steady and crisis states are lower in Nigerians, ${ }^{15}$ where crises values could be as low as $5 \mathrm{~g} / \mathrm{dl}$. It is noteworthy that crisis states among Nigerians are more likely to be of the haemolytic type. This may be related to G-6-PD deficiency in view of the reported high rate of G-6-PD deficiency among Nigerians. ${ }^{15}$ So, unlike a previous study, ${ }^{12}$ ours shows that both serum bilirubin and haemoglobin levels are affected during painful vaso-occlusive crisis.

The increase in $\mathrm{LDH}$ is an inherent manifestation of sickle cell disease due to the con- 
tinuous haemolytic events and release from infarcted bone marrow. Infarcted muscles which release creatinine kinase ${ }^{20}$ may also release the muscle $\mathrm{LDH}$ isoenzyme. The significantly higher level in crisis is a reflection of the severity of the event. No correlation was, however, found between LDH rise and haemoglobin depression, as both occurred independently.

The mean $\alpha-\mathrm{HBDH}$ level is higher in sickle cell disease patients than in control subjects. However, only $56 \%$ of the patients actually had levels higher than normal, though during crisis, this increased to $80 \%$. The source of this raised enzyme in sickle cell disease may be necrotic bone marrow and in vivo haemolysis. However, because of the relative specificity of $\mathrm{HBDH}$ assays to cardiac events, it is probable that the major source could be infarcted cardiac muscle. This is supported by the frequent observation of "large heart" in children who die during sickle cell crises. ${ }^{21}$ It is thought that hypoxic damage to cells, and the tissue ischaemia which occurs in sickle cell disease crises, is implicated in this phenomenon. Thus the measurement of this predominantly heart specific enzyme could be used as a marker for monitoring severity and progression of crises.

These results give us more insight into what may be happening to various biochemical indices in sickle cell disease. They show that pathophysiological and biochemical manifestations of the disease are similar irrespective of the geographical location of the patients. What differs is the severity of the manifestations. This could be the result of local factors, ${ }^{15}$ and in some cases of ameliorating factors such as haemoglobin $\mathrm{F}(\mathrm{HbF})$ in Saudis.

Assays of some of these variables show definitive differences between steady state and crisis state in this and other populations. Because of the relative ease with which these indices can be measured, they can be adapted for use both as biochemical markers for sickle cell disease crises and as tools to monitor the severity and progression of crises.

1 Karayalin G, Lanzkowsky P, Kazi AB. Serum $\alpha$-hydroxybuyrate dehydrogenase levels in children with sickle cell disease. Am 7 Pediatr Hematol Oncol 1981;3:169-71.

2 Nduka N, Ekeke GI. Serum calcium and protein in haemoglobin-SS patients. Folia Haematol 1987;114:508-11.

3 Ekeke GI, Nduka N. The antisickling role of uric acid in sickle cell disease. Trop Geogr Med 1987;39:152-6.

4 El-Hazmi MAF, Al-Faleh FZ, Warsy AS. Plasma uric acid urea and creatinine in sickle cell disease. Saudi Med $\mathcal{f}$ 1989;10:471-6.

5 Neely CL, Wajima T, Kraus AP, Diggs LW, Barreras L. Lactic acid dehydrogenase activity and plasma hemoglobin elevations in sickle cell disease. Am $\mathcal{F}$ Clin Pathol 1969, 52:167-9.

6 Muhammed S, Addae S, Suleiman S, Adzaku F, Annobil $\mathrm{S}$, Kaddoumi $\mathrm{O}$, et al. Serum calcium, parathyroid hormone, and vitamin D status in children and young adults with sickle cell disease. Ann Clin Biochem 1993;30:45-51.

with sickle cell disease. Ann Clin Biochem 1993;30:45-51. Al-Dabbagh AA, Acquaye JK, Al-Baghdadai TM, El-
Zamzamy MM. Radiological bone changes of sickle cell Zamzamy MM. Radiological bone changes of sickle cell anaemia in

8 Perrine RP, Pembrey ME, John P, Perrine S, Shoup F Natural history of sickle cell anaemia in Saudi Arabia. A study of 270 subjects. Ann Intern Med 1978;88:1-6.

9 Acquaye JK, Omer A, Ganeshaguru K, Sejeny SA Hoffbrand V. Non-benign sickle cell anaemia in Saudi Arabia. Br $\mathcal{F}$ Haematol 1985;60:90-108.

10 Morgan AG, De Ceulaer K, Sergeant GR. Glomerular function and hyperuricemia in sickle cell disease. $\mathcal{F}$ Clin Pathol 1984;37:1046-9.

11 Reynolds MD. Gout and hyperuricemia associated with sickle cell anaemia. Semin Arthritis Rheum 1983;12:404 13.

12 Iuchi I, Diggs LW, Upshaw JD. Benzidine-positive pigments in serum of patients with sickle cell anaemia during painful in serum of patients with sickle cell anae

13 White JM, Billimoria F, Muller MA, Davis LR, Stroud CE. Serum alpha-hydroxybutyrate levels in sickle cell disease and sickle cell crisis. Lancet 1978;i:532-3.

14 Sergeant GR. Observations on the epidemiology of sickle cell disease. Trans $R$ Soc Trop Med 1981;75:228-31.

15 Nduka N, Maxwell-Owhochuku S, Odike P. Current observations on sickle cell genotype in Nigeria. $E$ Afr Med $\mathcal{F}$ 1993;70:646-9.

16 Gold MS, Williams JC, Spivack M, Grann V. Sickle cel anaemia and hyperuricemia. $\mathcal{f} A M A$ 1968;206:1572-3.

17 Adeyokunnu AA, Osayintuyi YO. Serum uric acid status of Nigerian children with sickle cell disease. $E$ Afr Med $\mathcal{f}$ 1984;6:145-9.

18 Morgan AG, Sergeant GR. Renal function in patients over 40 with homozygous sickle cell disease. BMF 1981;282: 40 with

19 Schubert TT. Hepatobiliary system in sickle cell disease. Gastroenterology 1986;90:2013-21.

20 Hunt BJ, Korsah P, Eaton S, Brozovic M, Creatine kinase activity in sickle cell disease. $\mathcal{F}$ Clin Pathol 1989;42:712-5.

21 Annobil SH, Adzaku F, Addae SK, Mustapha S. Strokes in sicklers (children) at high and low altitudes. Abstracts of fifth meeting of National Working Group on Haemoglobinopathies, Abha, Saudi Arabia, 1994:14. 